\title{
Infield grass production at northern latitudes: farmers' adaptations to climate change
}

\author{
Atle Mysterud $^{1, *}$, Anders Nielsen $^{1}$, Øystein Holand ${ }^{2}$ \\ ${ }^{1}$ Centre for Ecological and Evolutionary Synthesis (CEES), Department of Biology, University of Oslo, PO Box 1066 Blindern, \\ 0316 Oslo, Norway \\ ${ }^{2}$ Department of Animal and Aquacultural Sciences, Norwegian University of Life Sciences, PO Box 5025, 1430 Ås, Norway
}

\begin{abstract}
Livestock production at northern latitudes involves many stages that each can be affected by climate change. The infields around the farms are typically used for producing grass for winter fodder. We analysed a unique dataset from the Norwegian dairy farmers association (TINE) from 1993 to 2009 on timing of the 1st infield harvest, the proportion of multiple harvests in a season, and the quality of the harvest in terms of protein content. We selected data from farmers using Setesdal $(\mathrm{n}=4475)$, Hardangervidda $(\mathrm{n}=658)$ and Forollhogna $(\mathrm{n}=2719)$ in Norway as their outfield alpine summer ranges. Average timing of the 1st harvest became earlier in all areas over the last 2 decades, but more so in the northernmost area (Forollhogna). This allowed an increase in the proportion of farmers with a 2nd infield harvest in the north (Forollhogna) and a 3rd harvest in the south (Setesdal), but with no change in the middle (Hardangervidda). Timing of the 1st harvest was not related to May temperatures but was marginally earlier when previous winter conditions were mild and there was little snow (high value of the North Atlantic Oscillation), except for Hardangervidda. The quality of the 1st harvest showed no clear pattern of development over time. Our study quantifies how farmers are adapting to climate change by timing their infield harvest to an earlier arrival of spring. We highlight the necessity of considering all stages of the production cycle of livestock when assessing the effect of climate change at northern latitudes.
\end{abstract}

KEY WORDS: Climate $\cdot$ Sheep $\cdot$ Livestock $\cdot$ Infield $\cdot$ Grass production $\cdot$ Phenology

\section{INTRODUCTION}

Human food production is likely to be affected by current climate change, although the extent of this effect is uncertain (Battisti \& Naylor 2009, Herrero et al. 2010). Climate change has already affected the production of a variety of crops (Olesen \& Bindi 2002, Supit et al. 2010, Bindi \& Olesen 2011). Livestock production involves many stages that each can be affected by climate change. At northern latitudes or at high altitude alpine habitats, sheep production normally involves both infield and outfield grazing, in addition to winter feeding with commercial concentrate and forage produced on infields the previous summer. Currently, most attention has been paid to how climate affects the outfield grazing season for the pro- duction of cattle (Craine et al. 2010) and sheep (Mysterud et al. 2001b, Nielsen et al. 2012). It is also central to know how farmers might adapt to change the infield part of the production cycle (Crane et al. 2011).

Timing is crucial for agricultural production that faces a short growing season and the harsh northern climate. An agro-pastoral based production system has evolved to facilitate utilization of a limited amount of cultivated land but extensive lush summer pastures. In Norway, $44 \%$ of the country is mountainous with rangelands, while infield agricultural pastures account for only $3.2 \%$ of the area (Statistics Norway www.ssb.no/emner/01/01/areal/). The infields are crucial for husbandry as the grass used for winter fodder for both cattle and sheep are produced there. The long winter period (October to April) con- 
sists of indoor feeding mainly with forage produced in the infield during summer. Roughage (silage) of high quality is crucial to reduce input of concentrate and hence secure a sustainable and economically viable industry based on locally produced resources. The infields thus play an important role in the production cycle, but how climate and timing of spring affect the infield production system has not been quantified in detail. Phenological development of pasture grasses is a product of both mean daily temperature and daylight length. Over the last 3 decades, productivity - as measured by the Normalized Difference Vegetation Index (NDVI) - has increased at northern latitudes (Myneni et al. 1997, Slayback et al. 2003, Karlsen et al. 2009), and spring has come earlier, in particular at low altitudes. It is therefore likely that infield production rates will increase, which may affect forage quality and yield.

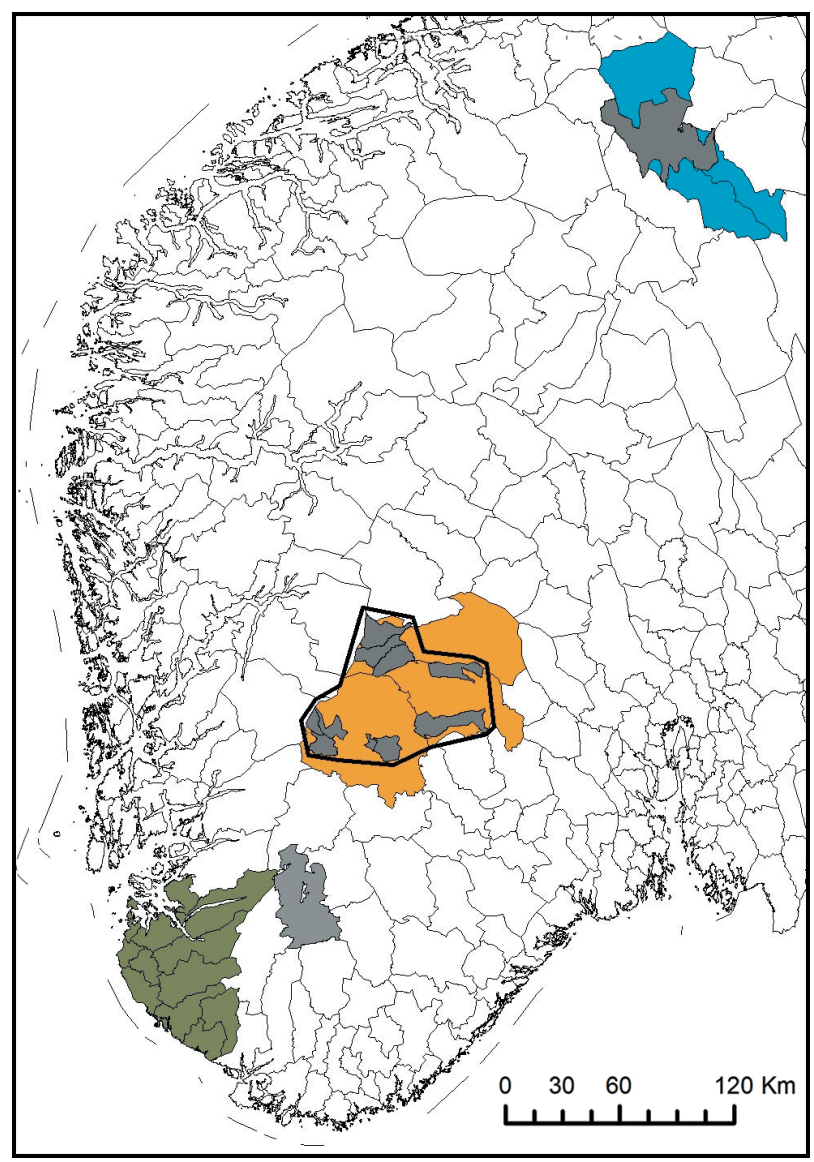

Fig. 1. Municipalities in southern Norway with registered infield grazing and winter fodder production. Blue: Forollhogna; yellow: Hardangervidda; green: Setesdal Vesthei; grey: outfield grazing. Thick black line: total extent of eastern part of Hardangervidda mountain range. Note that the outfield grazing areas are totally separated from municipalities where the infield grazing takes place in Setesdal while there is an overlap in Hardangervidda and Forollhogna
In this study, we analyse a unique dataset from the Norwegian dairy farmers' cooperative association (TINE) on the timing, number, and forage quality of infield harvest from the period 1993-2009. We focus on data from areas with sheep-farm infield pastures; these farms use 3 main alpine ranges in southern Norway as their summer outfield pastures: Setesdal Vesthei in the south, Hardangervidda in the central region and Forollhogna in the north (Fig. 1). We quantify if farmers adapt to current climate change, and test the hypotheses $(\mathrm{H})$ that the timing of harvesting of the infield have become earlier over the last 2 decades $\left(\mathrm{H}_{1 \mathrm{a}}\right)$, and more so in the north (Forollhogna) than in the south (Setesdal) $\left(\mathrm{H}_{1 \mathrm{~b}}\right)$; that earlier first harvest may allow for 2nd or 3rd harvesting of the infield (i.e. increased yield) $\left(\mathrm{H}_{2}\right)$, and that this may have a negative effect on forage quality (measured by protein content) $\left(\mathrm{H}_{3}\right)$. Lastly, we test whether these changes are either related to winter conditions (such as the winter index of the North Atlantic Oscillations [NAO]; Hurrell 1995, Hurrell et al. 2003) $\left(\mathrm{H}_{4 \mathrm{a}}\right)$ or temperature in early summer $\left(\mathrm{H}_{4 \mathrm{~b}}\right)$.

\section{MATERIALS AND METHODS}

\subsection{Study areas}

Our study areas were chosen according to the location in southern Norway of sheep-farm infields and the adjacent mountain ranges used as summer pastures: Setesdal Vesthei, Hardangervidda and Forollhogna (Fig. 1).

Sheep farmers using Setesdal Vesthei (hereafter Setesdal) as summer pastures have infields on Jæren in Rogaland county, the municipalities Egersund, Sandnes, Sokndal, Lund, Bjerkreim, Hå, Klepp, Time, Gjesdal, Sola, Randaberg, Forsand and Strand. These are coastal areas at low altitude and latitude quite far from the summer grazing areas, with a mean elevation of $40 \mathrm{~m}$ and ranging from 0 to $1304 \mathrm{~m}$ above sea level (a.s.l.). The infields are at low altitude compared to the outfield areas. This tradition of longdistance moving of livestock from Jæren to Setesdal is more than a century old (Mysterud \& Mysterud 1999).

Hardangervidda is the largest mountain plateau in southern Norway. Sheep farmers using these outfield summer pastures come from both the eastern and western side of the mountains, which have very different climates. Data from western parts (municipalities Ullensvang, Eidfjord and Odda) were extremely limited, and therefore excluded from analysis. The 
results presented here are thus all from the eastern inland side of Hardangervidda, municipalities Vinje and Tinn in Telemark, and Nore og Uvdal in Buskerud county. The mean elevation of these municipalities is $1110 \mathrm{~m}$ a.s.l., and range from 200 to $1880 \mathrm{~m}$ a.s.l. The municipalities for users of Hardangervidda have infield production further inland, more similar to those in Forollhogna, and at a much higher altitude than those in Jæren/Setesdal.

Forollhogna is the northernmost area, and is at a slightly lower altitude. The users come from the municipalities Os and Tolga in Hedmark and Midtre Gauldal in Sør-Trøndelag, with a mean elevation of $818 \mathrm{~m}$, ranging from 60 to $1600 \mathrm{~m}$ a.s.l.

For the period 1992-2007, average temperatures were $3.7^{\circ} \mathrm{C}$ in Forollhogna, $6.8^{\circ} \mathrm{C}$ in Hardangervidda and $8.9^{\circ} \mathrm{C}$ in Setesdal; annual precipitation was 34.9, 46.2 and $110.3 \mathrm{~mm}$ respectively in Forollhogna, Hardangervidda and Setesdal. Growing degree days (GDD, the amount of time with temperature $>5^{\circ} \mathrm{C}$ ) was 58.1, 131.4 and 182.5 GDD for Forollhogna, Hardangervidda and Setesdal, respectively (Nielsen et al. 2012).

\subsection{Data on infield harvesting}

TINE established a service for mesuring quality of forage in 1993: farmers can send in their silage/ roughage samples, which are measured for crude protein $(\mathrm{CP})$, fibre, neutral detergent fibre (NDF, the fraction remaining after dissolution of non-fibrous material with a neutral detergent solution), digestible energy (feed units; 1 unit = digestible energy of $1 \mathrm{~kg}$ barley), and dry matter content. Data also include forage type, harvesting/cutting dates and whether it was 1st, 2nd or 3rd harvest. We limited analysis here to silage, as this is by far the most dominant feed type in all areas, and is most relevant for sheep production. Sample sizes were 4475 for Setesdal, 658 for Hardangervidda and 2719 for Forollhogna for 19932009 (see Table S1 in the supplement at www.intres.com/articles/suppl/c053p055_supp.pdf). We only included data sampled between 15 May and 27 September. Each sample represents 1 silage sample from 1 harvest from 1 farmer. Note that these samples come from dairy farmers that may or may not have sheep on the farm. Farmers produce fodder for sheep and cattle in the same way, so it is highly likely these are representative for all grass production in each region. Among the dairy farmers, $42 \%$ in Setesdal, $9 \%$ in Hardangervidda and $11 \%$ in Forollhogna also had $\geq 10$ adult sheep (statistics based on those applying for production of both species; Norwegian Agricultural Authority). However, as we discuss in Section 4, dairy and sheep farmers may differ in their use of infields for spring and autumn grazing, which may affect the pattern of harvesting.

\subsection{Climatic data}

We retrieved data on average temperature in May from weather stations run by the Meteorological Institute of Norway (station numbers-Setesdal/Jæren: 46910 Nedre Vats; Hardangervidda: 37230 Tveitsund; Forollhogna: 16610 Fokstugu). Weather data were missing in 1998 for Setesdal. We therefore used an estimated value for 1998 with the aid of a linear regression on data from a neighbouring weather station (Sirdal, station no. 42920; r = 0.925 for common years). Data on winter indicies of the NAO (both station- and PCA-based for months December to March) were downloaded from the webpages of J. Hurrell (www.cgd.ucar.edu/cas/jhurrell/indices.html). The NAO winter index was chosen based on its reported strong influence on winter conditions in southern Norway (Mysterud et al. 2001c). As there was a high correlation between the station- and PCA-based in$\operatorname{dex}(r=0.925)$, we only report estimates using the PCA-based index.

\subsection{Statistical analyses}

We used generalized linear mixed models for analyses in the library 'lme4' (Bates \& Maechler 2009) in $\mathrm{R}$ version 9.2.0 (R Development Core Team 2010). We used generalized linear models for plotting. When testing for time trends $\left(\mathrm{H}_{1-3}\right)$, we entered 'year' as a continuous term (scaled to start at year 1993) and 'area' as a 3 level factor (Setesdal, Hardangervidda, Forollhogna). In all models, we used 'municipality' and 'year' as random terms. We compared models using the Akaike Information Criterion (AIC): lower values indicate a more parsimonious and better model in the sense of balancing explained variance with complexity of the model (Burnham \& Anderson 2002).

Model fit of logistic regression models (i.e. binary response) was tested using goodness-of-fit with the library 'Design' in R. We tested model fit for models lacking random terms, as testing fit of mixed-models is not straightforward. If fit of such a simpler model is adequate, a more complicated model including random terms will fit the data even better. 
For analyses of forage quality, we first performed a Principal Component Analysis (PCA) to see how related the quality measures were (see Fig. S1 in the supplement at www.int-res.com/articles/suppl/c053 p055_supp.pdf). The first axis (PCA1) explained $57.4 \%$ of the variation, and loadings suggested that feed units (-0.415), fibre (0.523), NDF (0.542) and protein content $(-0.469)$ were all positively or negatively correlated with PCA1, while the 2nd axis (PCA2) was mainly determined by the level of dry matter (loadings: PCA1 $=-0.202$, PCA2 $=-0.938$ ). Due to much lower sample sizes of feed units and NDF, we therefore analysed protein content as a proxy also for these. As protein content was given as a percentage, we arcsin-square-root transformed the variable before analyses.

\section{RESULTS}

\subsection{Timing of harvest}

As predicted by $\mathrm{H}_{1}$, the infield harvesting has come earlier over the last 2 decades (Fig. 2). This trend was more marked in the northernmost area of Forollhogna, supporting $\mathrm{H}_{1 \mathrm{~b}}$. Harvesting of the infield came earlier in the south (Jæren) using Setesdal as their summer outfield grazing area, and latest in the northernmost area, Forollhogna (Fig. 2, Table 1). Temperature in May was not included in the best models and was not a significant predictor of timing of the harvest (see Table S2 in the supplement at www.int-res.com/articles/suppl/c053p055_supp.pdf); thus $\mathrm{H}_{4 \mathrm{a}}$ was rejected. The inclusion of the winter-
NAO and its interaction between areas marginally improved AIC (Table S2 in the supplement). The effect of the NAO and its interaction between areas was not quite significant, but there was a tendency for earlier harvesting after high NAO in Forollhogna and Setesdal, but not in Hardangervidda (Table 1).

\subsection{Proportion of multiple harvests}

We found support for $\mathrm{H}_{2}$ : earlier 1st harvesting enables farmers to have a higher proportion of multiple harvests in more recent years. The trend over years was a higher proportion of multiple infield harvesting in Setesdal (Jæren) and Forollhogna, while there was no clear trend for Hardangervidda (Table 2, Fig. 2). Adding an interaction term between year and area resulted in a more parsimonious model (see Table S3 in the supplement at www.intres.com/articles/suppl/c053p055_supp.pdf). Multiple harvesting was much more common in the south (Setesdal/Jæren) than for areas surrounding Hardangervidda or Forollhogna further north. Indeed, while the year trend in Forollhogna was due to farmers increasing from 1 to 2 harvests, the trend was driven by a transition from 1 to 2 to 3 harvests for Setesdal/Jæren (Table S1 in the supplement). The model had a good fit to the data, as assessed using a goodness-of-fit test on a model without the random terms $(Z=1.640, p=0.101)$. There was no effect of either May temperature nor the NAO on the proportion of multiple harvesting, as inclusion of their effects largely increased the AIC value (Table S3 in the supplement).
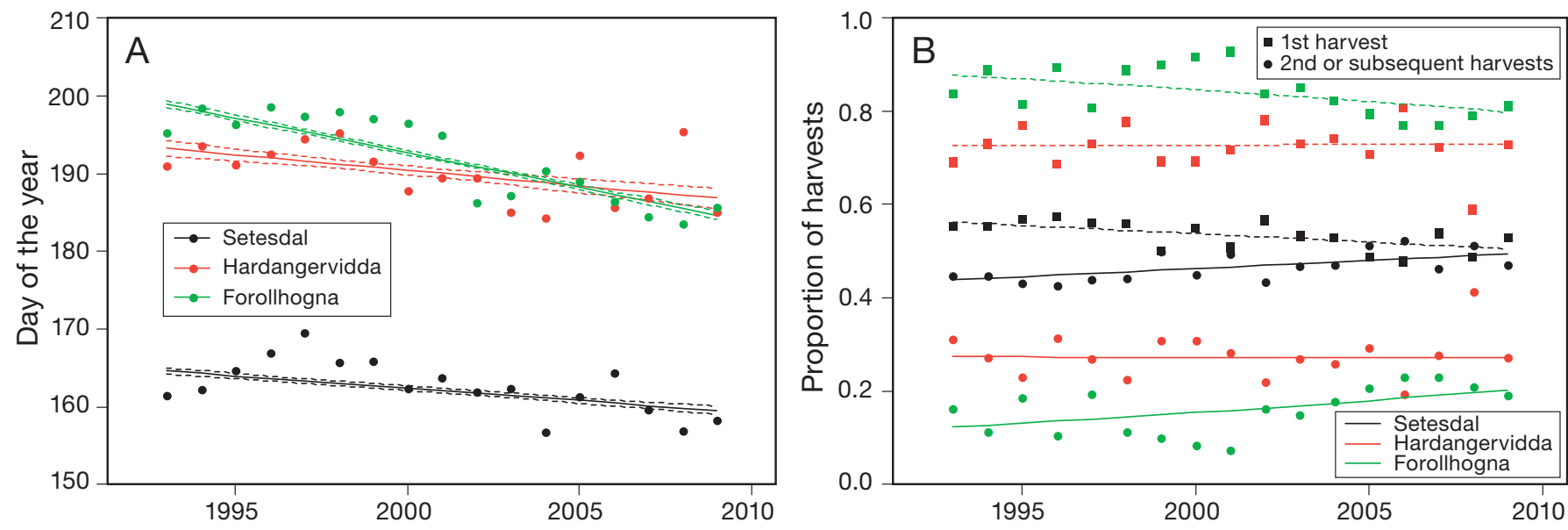

Fig. 2. (A) Timing of 1st annual harvesting of infields has changed over the last decades in Norway. This trend was more marked for the northernmost area: Forollhogna. Note that infield data are from the lowland areas surrounding the named alpine areas used for summer pastures. Solid lines: predicted values; dashed lines: SE. (B) Proportion of farmers harvesting more than once a year has increased in Norway following global warming. Solid lines: 1st harvest; dashed lines: 2nd harvest 
Table 1. Linear mixed effects (LME) analysis of how timing of 1st harvesting of infield has changed over time (1993-2009) for users of outfield grazing ranges in Setesdal (Jæren), Hardangervidda and Forollhogna, Norway. Municipality and year were entered as random terms. NAO: North Atlantic Oscillation

\begin{tabular}{|c|c|c|c|c|}
\hline & Estimate & SE & $\begin{array}{l}\text { Lower } \\
\text { limit }\end{array}$ & $\begin{array}{l}\text { Upper } \\
\text { limit }\end{array}$ \\
\hline Intercept & 193.6327 & 1.99442 & 189.644 & 197.622 \\
\hline $\begin{array}{l}\text { Area (Hardangervidda vs. } \\
\text { Forollhogna) }\end{array}$ & -5.32152 & 2.78668 & -10.895 & 0.252 \\
\hline $\begin{array}{l}\text { Area (Setesdal vs. } \\
\text { Forollhogna) }\end{array}$ & -29.4828 & 2.16656 & -33.816 & -25.150 \\
\hline $\begin{array}{l}\text { Scale(year) } \\
\text { Winter-NAO }\end{array}$ & $\begin{array}{l}-5.16248 \\
-1.10343\end{array}$ & $\begin{array}{l}0.54616 \\
0.58359\end{array}$ & $\begin{array}{l}-6.255 \\
-2.271\end{array}$ & $\begin{array}{r}-4.070 \\
0.064\end{array}$ \\
\hline $\begin{array}{l}\text { Scale(year): area } \\
\text { (Hardangervidda) }\end{array}$ & 3.11343 & 0.69055 & 1.732 & 4.495 \\
\hline Scale(year): area (Setesdal) & 2.99097 & 0.36597 & 2.259 & 3.723 \\
\hline $\begin{array}{l}\text { Winter-NAO: area } \\
\text { (Hardangervidda) }\end{array}$ & 1.23311 & 0.63688 & -0.041 & 2.507 \\
\hline Winter-NAO: area (Setesdal) & -0.04261 & 10.40209 & -0.847 & 0.762 \\
\hline
\end{tabular}

Table 2. Generalized linear mixed model analyses of changes in proportion of single vs. multiple ( $\geq 2$ ) infield harvests (1993-2009) for users of outfield grazing ranges in Setesdal (Jæren), Hardangervidda and Forollhogna, Norway. Municipality and year were entered as random terms

\begin{tabular}{|lrrrr|}
\hline & Estimate & SE & $\begin{array}{r}\text { Lower } \\
\text { limit }\end{array}$ & $\begin{array}{c}\text { Upper } \\
\text { limit }\end{array}$ \\
\hline Intercept & -1.723 & 0.094 & -1.911 & -1.535 \\
Area (Hardangervidda vs. & 0.780 & 0.153 & 0.475 & 1.086 \\
$\begin{array}{l}\text { Forollhogna) } \\
\text { Area (Setesdal vs. }\end{array}$ & 1.531 & 0.107 & 1.317 & 1.745 \\
$\begin{array}{l}\text { Forollhogna) } \\
\text { Scale(year) }\end{array}$ & 0.184 & 0.053 & 0.077 & 0.291 \\
$\begin{array}{l}\text { Scale(year): area } \\
\text { (Hardangervidda) }\end{array}$ & -0.180 & 0.113 & -0.407 & 0.046 \\
Scale(year): area (Setesdal) & -0.124 & 0.062 & -0.247 & -0.001 \\
\hline
\end{tabular}

age based forage, mainly grass in form of hay, often collected from semi-natural grasslands. Today, winter forage in the cattle and sheep farming industry is based on roughage harvested from perennial cultivated grasslands. We provide evidence that farmers are adapting their infield production system by earlier 1st harvesting, enabling also a higher proportion of multiple harvests. Harvesting is coming earlier both in the south (Setesdal) and the north (Forollhogna), though the effect is strongest in the north. This is consistent with earlier plant phenological development at these latitudes, as has been expected due to shorter winters and earlier springs at northern latitudes (Kausrud et al. 2008) and assessed by the NDVI (Myneni et al. 1997, Slayback et al. 2003, Karlsen et al. 2009). An average of $0.27 \mathrm{~d} \mathrm{yr}^{-1}$ earlier onset of growing season was found for all of Fennoscandia using the NDVI, with up to $1 \mathrm{~d} \mathrm{yr}^{-1}$ in southern and oceanic regions (Karlsen et al. 2009). In our areas, it was 0.89, 0.40 and $0.32 \mathrm{~d} \mathrm{yr}^{-1}$ earlier onset for Forollhogna, Hardangervidda and Setesdal, respectively (Fig. 2). This provides the first evidence that farmers at northern latitudes are adapting to and benefitting from climate change, as has been predicted (Olesen \& Bindi 2002). We found no clear evidence in the importance of early summer temperature $\left(\mathrm{H}_{4 \mathrm{~b}}\right)$, but some evidence that winter NAO $\left(\mathrm{H}_{4 \mathrm{a}}\right)$ affects the timing of the 1st harvest. This suggests that farmers are only to a limited degree responding to the

\subsection{Quality of the harvest}

The forage quality of the harvest was not markedly affected by recent climate change, rejecting $\mathrm{H}_{3}$. We found no variable that was related to protein content in the 1st harvest, as the baseline model (with only a constant) largely outcompeted models including area, day of the year of harvest, year as a trend (see Fig. S2 in the supplement at www.int-res.com/articles/suppl/ c053p055_supp.pdf), May temperature, or the NAO winter index (see Table S4 in the supplement at www.int-res.com/articles/suppl/c053p055_supp.pdf).

\section{DISCUSSION}

The long winter season at northern latitudes has historically necessitated extensive collection of rough- current year weather conditions.

The largest effects of climate change are predicted at the lowest elevation in the Alps and Fennoscandian mountains (Guisan et al. 1995). The agropastoral livestock production in these systems has always involved seasonal migration of the herd from near farm areas in the valley bottoms during winter to alpine, high-altitude ranges during summer (Kvamme 1988, Moe et al. 1988). Mysterud et al. (2001b) demonstrated that sheep body growth is affected by winter snow deposition in the mountains in regions where summer foraging is in coastal areas along the south-west coast of Norway. Lamb body mass in autumn is higher after winters with a high index of NAO, likely due to the positive effect of delayed phenology on late summer plant quality (Albon \& Langvatn 1992, Mysterud et al. 2001a, Hebblewhite et al. 2008). Cervids in Norway are also 
affected by the winter NAO (Mysterud et al. 2001b, Grøtan et al. 2005, Herfindal et al. 2006), including semi-domestic reindeer (Weladji \& Holand 2003). Nielsen et al. (2012) have recently expanded these analyses considering the Setesdal, Hardangervidda and Forollhogna alpine ranges, yielding evidence that the NAO operates mainly through snow depth. Currently, global change has resulted in slightly more snow in the mountains of Norway, but with spring arriving earlier (Kausrud et al. 2008). However, given the projected disappearance of snowcovered areas remaining over summer at altitudes of $\sim 1000 \mathrm{~m}$ elevation within the next century (Guisan et al. 1995), the longer-term consequences of climate change on outfield grazing may be negative, as these are important summer grazing areas due to newly emergent, high quality forage late in the growing season. The increased infield production reported here, in terms of number of harvests, might therefore become even more important in the future as it has the potential to buffer reduced alpine outfield production.

New cutting and conservation (preservation) techniques have revolutionized grass harvesting over the last decades, and may also play a role for the development in harvesting schedules. The increased harvesting capacity rate enables farmers to time the harvest accurately, and to potentially increase the number of cuttings. We provide evidence that farmers on Jæren/Setesdal and Forollhogna indeed have increased the proportion of multiple harvesting during summer now that climate conditions are becoming more favourable for such production. There was no such development for farmers around Hardangervidda. It is currently not clear whether this is due to the fact that 1 harvest is sufficient for most farmers around Hardangervidda to sustain their current livestock, or whether they use the infield more in spring and autumn for grazing, allowing for only 1 harvest. Many sheep farmers have to trade-off between using the infields for grazing in spring and autumn, and how many cuttings of the infields they should take during summer. The increase in proportion of cuttings may therefore also be driven partly by dairy farmers not having such constraints. Unfortunately, we have no data on the size of the 1st harvest itself, which is also an important measure of yield that may be affected by climate change. There is also a market for selling forage, but this is highly variable among years depending on the total annual production.

Agro-pastoral livestock production systems at northern latitudes have a complex cycle in which all steps will be affected by future global change. The infield production cycle seems to benefit from increased temperatures, and more so in the northernmost areas. However, we need to consider all stages of the production cycle of livestock before concluding how climate change will affect livestock production in these northern ecosystems.

Acknowledgements. This study was funded by the Research Council of Norway over the Mat-program (SauKlim project; No. 192864). We are grateful to L. Bævre and I. Schei at TINE for giving us access to the data. We are grateful to J. Seldal for giving information on municipalities of the members of Jæren smalelag, and to M. Angeloff for retrieving data on dairy and sheep farmers from the Norwegian Agricultural Authority. We are grateful for the discussion with A. O. Skjelvåg and K. A. Wilberg.

\section{LITERATURE CITED}

Albon SD, Langvatn R (1992) Plant phenology and the benefits of migration in a temperate ungulate. Oikos 65: 502-513

Bates D, Maechler M (2009) lme4: linear mixed-effects models using S4 classes. R package version 0.999375-32, available at: http://CRAN.R-project.org/package=lme4

Battisti DS, Naylor RL (2009) Historical warnings of future food insecurity with unprecedented seasonal heat. Science 323:240-244

Bindi M, Olesen JE (2011) The responses of agriculture in Europe to climate change. Reg Environ Change 11: S151-S158

Burnham KP, Anderson DR (2002) Model selection and multimodel inference: a practical information-theoretic approach. Springer, New York, NY

Craine JM, Elmore AJ, Olson KC, Tolleson D (2010) Climate change and cattle nutritional stress. Global Change Biol 16:2901-2911

Crane TA, Roncoli C, Hoogenboom G (2011) Adaptation to climate change and climate variability: the importance of understanding agriculture as performance. NJAS: Wagening J Life Sci 57:179-185

Grøtan V, Sæther BE, Engen S, Solberg EJ and others (2005) Climate causes large-scale spatial synchrony in population fluctuations of a temperate herbivore. Ecology 86: $1472-1482$

Guisan A, Holten JI, Spichiger R, Tessier L (1995) Potential ecological impacts of climate change in the Alps and Fennoscandian mountains. An annex to the Intergovernmental Panel on Climate Change (IPCC) Second Assessment Report, Working Group II-C (Impacts of climate change on mountain regions). Conservatoire et Jardin botaniques de la Ville de Genève, Geneva

- Hebblewhite M, Merrill E, McDermid G (2008) A multiscale test of the forage maturation hypothesis in a partially migratory ungulate population. Ecol Monogr 78: 141-166

Herfindal I, Sæther BE, Solberg EJ, Andersen R, Høgda KA (2006) Population characteristics predict responses in moose body mass to temporal variation in the environment. J Anim Ecol 75:1110-1118

Herrero M, Thornton PK, Notenbaert AM, Wood S, and others (2010) Smart investments in sustainable food pro- 
duction: revisiting mixed crop-livestock systems. Science 327:822-825

Hurrell JW (1995) Decadal trends in the North Atlantic Oscillation: regional temperatures and precipitation. Science 269:676-679

Hurrell JW, Kushnir Y, Ottersen G, Visbeck M (2003) The North Atlantic Oscillation: climatic significance and environmental impact. American Geophysical Union, Washington, DC

Karlsen SR, Høgda KA, Wielgolaski FE, Tolvanen A, Tømmervik H, Poikolainen J, Kubin E (2009) Growing-season trends in Fennoscandia 1982-2006, determined from satellite and phenology data. Clim Res 39:275-286

Kausrud KL, Mysterud A, Steen H, Vik JO and others (2008) Linking climate change to lemming cycles. Nature 456: 93-98

Kvamme M (1988) Pollen analytical studies of mountain summer farming in Western Norway. In: Birks HH, Birks HJB, Kaland PE, Moe D (eds) The cultural landscape: past, present and future. Cambridge University Press, Cambridge, p 349-367

Moe D, Indrelid S, Fasteland A (1988) The Halne area, Hardangervidda. Use of a high mountain area during 5000 years: an interdisciplinary case study. In: Birks HH, Birks HJB, Kaland PE, Moe D (eds) The cultural landscape: past, present and future. Cambridge University Press, Cambridge, p 429-444

Myneni RB, Keeling CD, Tucker CJ, Asrar G, Nemani RR (1997) Increased plant growth in the northern high latitudes from 1981-1991. Nature 386:698-702

Mysterud A, Mysterud I (1999) Bærekraftig bruk og forvaltning av Setesdals Vesthei og Ryfylkeheiene. En utredning med spesiell vekt på økologiske effekter av husdyr-

Editorial responsibility: Gerrit Hoogenboom, Prosser, Washington, USA beiting i utmark. Utmarksnæring i Norge 1-99:1-197

Mysterud A, Langvatn R, Yoccoz NG, Stenseth NC (2001a) Plant phenology, migration and geographic variation in body weight of a large herbivore: the effect of a variable topography. J Anim Ecol 70:915-923

Mysterud A, Stenseth NC, Yoccoz NG, Langvatn R, Steinheim G (2001b) Nonlinear effects of large-scale climatic variability on wild and domestic herbivores. Nature 410: 1096-1099

Mysterud A, Yoccoz NG, Stenseth NC, Langvatn R (2001c) The effects of age, sex and density on body weight of Norwegian red deer: evidence of density-dependent senescence. Proc R Soc Lond Ser B 268:911-919

Nielsen A, Yoccoz NG, Steinheim G, Storvik GO and others (2012) Contrasting responses of herbivore performance to global environmental variability (NAO, NDVI) over short spatial scales in alpine ecosystems. Global Change Biol (in press)

Olesen JE, Bindi M (2002) Consequences of climate change for European agricultural productivity, land use and policy. Eur J Agron 16:239-262

R Development Core Team (2010) R: a language and environment for statistical computing. R Foundation for Statistical Computing, Vienna

Slayback DA, Pinzon JE, Los SO, Tucker CJ (2003) Northern hemispehere photosynthetic trends 1982-1999. Global Change Biol 9:1-15

Supit I, van Diepen CA, de Wit AJW, Kabat P, Baruth B, Ludwig F (2010) Recent changes in the climatic yield potential of various crops in Europe. Agric Syst 103:683-694

Weladji RB, Holand $\varnothing$ (2003) Global climate change and reindeer: effects of winter weather on the autumn weight and growth of calves. Oecologia 136:317-323

Submitted: June 14, 2011; Accepted: January 19, 2012

Proofs received from author(s): May 18, 2012 